\title{
Bridging the Sustainable Skills Gap in Business Education Curriculum for Post Oil Boom Economy in Nigeria
}

\author{
Owhoeke Nwameze George, Emeka Gift Nwokocha \\ School of Business Education, Federal College of Education (Technical), Omoku, Nigeria \\ Email address: \\ nwamezeogeorge@gmail.com (O. N. George), emekanwokoca@yahoo.com (E. G. Nwokocha)
}

\section{To cite this article:}

Owhoeke Nwameze George, Emeka Gift Nwokocha. Bridging the Sustainable Skills Gap in Business Education Curriculum for Post Oil Boom Economy in Nigeria. International Journal of Vocational Education and Training Research. Vol. 7, No. 1, 2021, pp. 6-13. doi: 10.11648/j.ijvetr.20210701.12

Received: December 16, 2020; Accepted: January 27, 2021; Published: April 30, 2021

\begin{abstract}
Business education curriculum was designed to prepare students for entry in advancement of jobs within business and to prepare them to handle their own business affairs and to function intelligently as consumers and citizens in a business economy. However, education offered at tertiary institutions especially business education programmes seem not to prepare graduates of business education to meet real life situations as tertiary institutions curriculum structure cannot be said to have attained the expected level of standard and quality. This paper therefore focused on the need for sustainable business education curriculum in Nigeria as a panacea for the post oil boom economy. The paper looked at the present business education programmes and its curriculum objectives. Attention was given to some key concept such as sustainable business education curriculum, prerequisite for sustainable education curriculum, sustainable business education curriculum for post oil boom economy, and bridging the sustainable curriculum gap in business education. The paper concluded that the need for sustainable curriculum in the post oil boom economy is imperative because of the experiences of the economy recession and the need for holistic industrial development of the economy. Finally, the paper recommended among others the re-assessment, re-evaluation and redesigning of the business education curriculum by educational institutions to meet its practical functionality in the Nigeria economy so as to reflect the $21^{\text {st }}$ century sustainability skills and culture for gainful and self-sustainable employment.
\end{abstract}

Keywords: Sustainable Skills, Business Education, Curriculum, Post Oil Boom

\section{Introduction}

Business Education as a programme was not given attention until the national policy on education of 1977 [2]. Business education programme was designed therefore, to teach both the concept of education and teaching of business in education. One of its prominent objectives was geared toward equipping students with saleable skills and knowledge that will enable them create and acquire jobs, stay on the jobs and grow in the jobs [2]. As a programme of study, business education focus on producing graduates who are adequately equip with relevant employability skills to be gainfully employed or be self-sufficiently sustainable. However, it is evident that, the current curriculum of business education has failed to achieve the laudable objectives of the programme, because substantial numbers of business education graduates are neither gainfully employed or selfreliance. The author further observed that the laudable programme of this new system of education of providing the knowledge, skills, understanding and attitude needed in the business world has failed to curs youth unemployment. Business education is a comparatively new developments in educational delivery system in most developing countries of Africa, Asia and Latin America. Business education is designed with the prime purpose of upgrading skills or providing individual with the necessary skills required to obtain gainful employment. Therefore, the programme is geared toward entry into particular jobs and the administration of the programmes towards the achievement of the goals [19].

Business education houses other programmes such as marketing, management, administration, accounting, office technology and management etc. It is therefore, an occupation building programme in which students develop skills for surviving in the business world. As an education based programme, business education creates a platform 
for the acquisition and development of various skills which cuts across the four dimension of learning domains: that is: cognitive, psychomotor, affective and perceptual. Business education demand for a holistic curriculum that can develop students both theoretically and practically for sustainable fulfillment of life pursuit, especially in the $21^{\text {st }}$ century. The development stated above are in the areas of curriculum trends, rapid industrialization, and urbanization, economic forces, new methodologies in the classrooms and offices [2]. In other words, the curriculum of the business education should be of a sustainable nature that has the potential to equip students with both practical and theoretical skills for sustainable gainful engagements. A sustainable business education curriculum prepares graduates beyond gainful employment. It builds in students skills that transcend the classroom knowledge. It is structure to expose student to self-reliant skills which are capable of positioning graduates beyond the world of work. In a nation like Nigeria where almost everything including job creation is based on the oil industry, many graduates find it difficult to fit into other sectors especially self-sufficient endeavours. However, the redesigning of business education curriculum towards self-sustainability will equip students beyond the oil boom economy. Thus, for business education graduates in Nigeria to avail themselves of the post oil boom job opportunities, it is imperative to boost the business education curriculum with improve contents that will usher in the saleable skills prerequisite for the post oil economy.

\section{Statement of the Problem}

One of the challenges facing Nigeria youths is the problem of finding suitable employment after graduation. This endemic challenge has plunge the nation into massive unemployment as a result of over reliance on the oil boom economy. Many graduates are unemployed or rather underemployed due to the failed nature of the Nigerian development agenda. However, the most prominent challenge of the youths is the issue of developing saleable skills with business orientation in the course of their academic pursuit, which is capable of placing them on the brink of self-reliant endeavors. To achieve a self-reliant system there is the need for paradigm shift in the business curriculum of the academic system of the educational institutions. This backdrop, has created a gap in the pursuit of employment by Nigerian graduates. Thus, this paper is carried out to bridge the sustainable skills gap in business education curriculum for post oil boom economy.

\section{Purpose of the Study}

The purpose of this paper is to determine how to bridge the sustainable skills gap in business education curriculum for post oil boom economy in Nigeria.

\section{Method of the Study}

This paper uses explanatory descriptive approach which is Narrative Textual Case Study (NTCS) method. This method was employed because the paper did not use sequential data. Narrative Textual Case Study is a social science research method that employs intensively information data (where necessary) and academic materials made available and accessible by information and communication technology facilities such as internet, e-libraries and others [1]. This paper is non-empirical, but basically opinion based research.

\section{Discussion}

\subsection{Sustainable Business Education Curriculum: The Case of the Nigerian Education System}

The concept of curriculum is a special field of learning that has to do with planning and designing of course content in order to achieve its laudable objective. The word curriculum is derived from the Latin word "Currus" meaning a "run way" or "running a course". A curriculum is a document which comprised of the goals and objectives of a particular course of study [2]. Curriculum is usually designed such that it capture issues like subject matter or content, the learning, the learning experiences and evaluation. Therefore, curriculums comprehensively spells out the materials and resources required to enhance teaching and learning [2]. A dynamic curriculum must have definite and self-motivated objectives, must be flexible and must have a built-in process of evaluation.

However, most curriculum design in the Nigeria educational system are not sustainable, because they cover course content which does not fulfill futuristic objectives. Besides most of the curriculum are primarily theoretical in nature without any glimmer of practical involvement especially the social sciences which business education belong. Considering the combination of the programmes that make up the business education study, it is imperative that the business education curriculum be designed to be sustainable. If the philosophy and objectives of business education is to be giving full consideration then the curriculum must be dynamic enough to express sustainable content that will serve future purpose of the students' post educational career.

A sustainable business education curriculum should emphasized on learning and doing. In other words it is practical oriented. The goal of business education is primarily to produce competent, skillful and dynamic business teachers, office administrators and business experts that will effectively compete in the world of work [12]. However, experience shows that many people lack interest in business education as a profession because they feel it is education for the less privilege or a programme which upon graduation lack job opportunities. This is because business education curriculum planners lack the professional who can design a uniform curriculum that can accommodate business education interest of all the universities in Nigeria [13]. 
It is pertinent therefore, to develop not just a uniform curriculum, but a sustainable curriculum that has the ingredients to build in students, skills and knowledge that are capable of exposing and expanding their knowledge of the business world and self-sustainable life after graduation. Thus, there should be a rethink on revising education from nursery school to university to include a clear focus on current and future societies on the development of knowledge skills, perspectives and values related to sustainability [9]. The author further stressed that this means reviews of existing curriculum in terms of its objectives and content to develop trans-disciplinary approaches to teaching, learning and assessment. Higher education has a critical role to play in producing sustainable students by helping them to understand the complex connections and interdependencies between the environment, energy sources, and the economy $[9,6]$.

To accomplish this, education requires a new way of thinking and learning about integrated systematic solutions not just to the economy, and environmental challenges, but also the interdependent between health, social, and political challenges. Above all this way of thinking uses the green economy as the focal point for understanding the deep connections between economics, energy, the environment and social well-being, offer referred to as sustainability (Elder, 2009). Thus, sustainable business education curriculum is geared towards greening the economy because it builds the learning of the future. Partnering the environment, society and education to find solution to the challenges of the immediate economy. The United Nations (UN) constituted 2005-2014 as the decades for educational sustainable development. This decades speaks to the bridges that must be built between academia and the needs for the community as well as the need to enact sustainability in higher education in order to positively affect the larger society and biosphere [16].

The obvious question here is: Has the business education programmes in Nigeria been able to bridge that gap? The answer is no, because the curriculum has not changed from its theory based teaching to sustainable based learning. The point here is that the green sustainable curriculum provides opportunities for students to develop holistically to function both as a public and private individual after graduation, i.e. they can be gainfully or self-employed.

To achieve this pursuit, the Ubuntu declaration [2], an initiative from education and scientific organizations all over the world, raised the following areas where universities have a role to play: review programmes and curricula in order to address the challenges of sustainable development; strengthen the role of teachers and attract young people to the profession; develop mechanisms to keep teachers informed; and promote knowledge transfers in innovative ways in order to bridge the gaps and inequalities of present knowledge. A local institutions position on a sustainable curriculum should be to model sustainable practices into the development of students that will enable them function and cope with future challenges. Therefore, it is important that academics and institutions keep experimenting with and sharing their efforts to embody sustainability, especially in making it a focus of their discipline and professions in the process of curriculum design, development and research [17].

\subsection{Prerequisite for Sustainable Business Education Curriculum in Nigeria}

The imperative of sustainable education curriculum in Nigeria is evident in that the school system has nosedived in the bid to produce self-sustainable graduates. Put simply, sustainability is about reducing our ecological footprint while simultaneously improving the quality of life that we value"the livability of our society" [4]. However, education for sustainability is both present and future oriented. It's about learning to design and implement actions for the present in the knowledge that the impact of these actions will be experienced in the future. In this way, it leads to students developing an overall capacity to contribute to a more sustainable future in terms of environmental integrity, economic liability and a just society for present and future generations [18]. Consequently, the first important need for a sustainable education curriculum is to develop and graduate students with futuristic focus. Students who have the potentials to fit into economic and environmental system of the nation both in a gainful and self-sustainable employments.

In another development, an era that is marked by concerns about the future of the Nation, education for sustainability can be empowering and an antidote to a sense of helplessness It equips students to act individually and collectively in ways that can contribute to sustainability [4]. Sustainable education curriculum enables students to explore and evaluate contested and emerging issues, gather information and create solutions for sustainable future. Such greening curriculum develop students to become affective citizens and active change agents by helping them to deal with complexity and uncertainty. It exposes students to tasks that are futuristic. It helps students to understand and develop multiple problem solving approach because new knowledge is continuously emerging.

Education for sustainability means that students will be able to assess competing viewpoints, values and interest, manage uncertainty and risk; make connections between seemingly unrelated concepts, ideas, and outcomes and test evidence and propose sustainability [4].

\subsection{Sustainable Business Education Curriculum for Post Oil Boom Economy in Nigeria}

The Nigeria economy is a mono-economy in which oil is the major revenue that sustains the government fiscal expenditure. The oil has sustained the economy for majority part of the existence of the nation. Huge income has been generated from the sales of crude oil, and in must time excess income is also accrued as a result of excess crude oil. The focus in the oil economy has made the nation lost sight of the potentials of other relevant sectors of the country such as the agricultural industry. Over reliance on crude oil has also killed the zeal and trust of many citizen in the viability of the 
country to develop its numerous sector.

However, the fact that oil will continue to boom and sustain Nigerian economy is not a reality, as evident in the recent drop in daily barrel of production has shown. Also, the fact that oil may dry-up in the future is as realistic as day light. Thus, largely relying on a mono-economy of crude oil since the 70's, the country appears blind to, and visibly indifferent to global attraction and shift to cleaner and cheaper energy source, including economic diversification [7]. The era of oil is ready, food is ready is almost over, only total realistic reformation would re-route Nigeria out of the vicious cycle of structural traps. Re-routing the Nigeria economy required that the focal point should be the educational system where her teeming generations of the youths and children are been prepared for future endeavors. Hence, the best way to re-route the Nigeria economy is to develop a curriculum that can build the citizens for a sustainable future, because "in vain you build the city, expect you first build the man".

The business industry is one core sector of the economy that has a sustainable potential. In this view, it is advisable that developing a curriculum that best fit the envisaged transformation is put in place in the educational sector. Business education as a programme prepares people for initial office or salesmanship jobs, and for managing selfowned and operated enterprises. It provides general knowledge and understanding for all persons regardless of age, occupations professions, social or economic status [2]. As a core business programme, it teaches both the business of education and the education of business. Thus its philosophical applications are not limited to business education.

It is of necessity that the curriculum of business education between all-encompassing and holistically accommodating. The curriculum should have a sustainable focus with emphasis on building reliable skills and competencies that will benefit the students in future. For a sustainable business education curriculum to be effective in the post oil boom economy it must accommodate the $21^{\text {st }}$ century skills. Such initiatives, creativity communication, self-reliance, expert novice, technological savvy, flexibility, resourcefulness and adaptability among many others. Opportunities to develop problem solving capabilities, team work, creativity and the use of technologies within the context of designing and making, are mentioned as goals in many technology education syntheses around the world [14]. These skills are otherwise known as employability skills. They are core generic key and life skills or competencies that play significant role in ensuring that young people specifics fits into the world of work.

A post oil boom business education curriculum should involve the technology education as part of it generic skills development [11]. Technology education will help business education to respond to economic development needs both individually and nationally. The sustainable curriculum identifies range of competencies covering broad economic and business environment firms specific knowledge and generic core competencies with some integrated into existing subject area to boost students' knowledge of surviving in the future. The emphasis of the pre-vocational curriculum was on general and transferable skills as per a core competencies model [14]. Self and social competencies as internal locus of control risk-taking communication ability and team ability were most important. The author further stated that in Germany, the wider economic and market environment and social and collective competences prevailed over competencies in business. These competencies were knowledge-based in the field of trade and globalization teamwork abilities and communication competencies.

In reality, while it is possible to take other core subject matters out of business education, it is practically impossible to take business education out of other core subjects' matters. The majority of skills development are related to up-skilling or adding to existing core skills to enable a person to fulfill a new occupation or fill into a new environment. Therefore, topping-up skills could be firm or industry specific for structured economies and job-specific for informal and nonformal economies and could be addressed through existing education and training system [14]. This is what sustainable business education curriculum seeks to achieve, by providing generic skills that are required in almost any occupation to understand and appreciate the issues and demands of the changing economic system.

A new national curriculum in Australia is taking shape and sustainability is an important consideration for organizing the curriculum [14]. In other words, nations are looking towards buildings a sustainable curriculum to secure the future of their economy. One of the most important needs for sustainable business education curriculum is changing nature of education which has technological imperative. Technology education is affecting schools and schooling system. The inclusion of generic green skills into technology education curriculum will help address economic needs of countries, and stimulate personal development of students [14]. In consonant with technology education, business education sustainable curriculum needs to address issues of innovation and green employability skills for economic and environmental redesigning of the future of the economy to address the challenges of transformation to a greener economy.

The curriculum offerings, especially at the tertiary levels cater for some of the requirements of the $21^{\text {st }}$ century skills, which are drawn from core and elective courses taken in other departments such as sociology and psychology [2]. In as much as this, graduates from business education programme join the ranks and files in unemployment and inability for those employed to carry out their assigned duties without further training. Thus, this create doubts as to the relevance, functionality and adequacy of the curriculum and its delivery system in meeting the demands of employability, either gainfully or self-sustainable. It therefore becomes relevant that the business education curriculum lack sustainability competencies in its contents and delivery system. 
Generally speaking, the educators comprising the administrators and the academics look forward to provide a critical curriculum to the students. They are the 'gate-keepers' of academic knowledge and intend to 'feed' the students with the necessary fundamental knowledge in the hope that the students can develop their repertoire of skills further [8]. Their perspectives on the business curriculum are highly 'about business' [10]. The business community has a relatively narrow perspective of business curriculum and requires the universities to provide business graduates with the necessary knowledge and skills that match those of the workplace [3]. They are extreme 'for businesses in their perspective. The authors further stated that the students also have a narrow perspective of business curriculum: they are 'to learn how to do things when we work for a company'. The point here is that to build a sustainable business education curriculum, there should be combined inputs of knowledge and ideas from government, administrator, academics and stakeholders in the systems. This is the only way to accommodate the interest of every profession in the 'about business' direction of business education. Lucas and Milford designed 'The 'for-about' spectrum of business education Diagram' as shown below:

\begin{tabular}{|c|l|l|}
\hline $\begin{array}{l}\text { 'Employers } \\
\text { Professional } \\
\text { bodies Student }\end{array}$ & $\begin{array}{l}\text { Accreditation bodies } \\
\text { and education policy }\end{array}$ & $\begin{array}{l}\text { Academic and } \\
\text { research } \\
\text { tradition }\end{array}$ \\
\hline \multicolumn{2}{|c|}{ about business' for business' } \\
\hline $\begin{array}{l}\text { Education for business } \\
\text { views management as a } \\
\text { set of competences }\end{array}$ & $\begin{array}{l}\text { Education about business } \\
\text { views management as set a } \\
\text { practice }\end{array}$ \\
\hline
\end{tabular}

Figure 1. The for-about spectrum business education.

\section{[Curled from 10]}

Lucas and Milford advise that the trend of business education in recent years has been a modification in the direction of 'for business' [10]. This is due to the pressures of demands from the government, employers, professional bodies, and the students. However, they point out two key forces that are supporting a shift towards 'about businesses. One is the changing view of the meaning of vocationalism to the business professionals. Another is the more formal approach to business programme design and the emphasis on pedagogy.

\subsection{Bridging the Sustainable Curriculum Gap in Business Education in Nigeria}

The contemporary business education curriculum is theory centered with little or no practical skill focus for selfsustainability. The content of the current curriculum has no futuristic focus, because it is basically geared towards preparing graduates for gainful employment (white-collar jobs). The acquisition of workplace skills is seen universally as a key driver of economic and technological development [17]. The purpose of workplace skills development is focus on building graduates whose main ambitions are to be gainfully employed; however, over the years it has seen proven that self-sustainable experiences and endeavors contributes to the development of micro-economic variables of aeration. Thus, it become imperative to look unto these sustainable skills especially as the nation is facing high rate of unemployment, and preparing to launch an economy is not based on soil production in the near future.

Technical and vocational education and train (TVET for which business education is a fragment) is a comprehensive term referring to those aspects of the educational process in addition to general education. The study of technologies and related sciences, and knowledge relating to occupation in various sectors of the economy and social life (UNESCO, 2001). The UNESCO report stated that TVET is (i) an integral part of general education (ii) a means of preparing for occupational field and effective participation in the world of work; (iii) an aspect of lifelong learning and preparation for responsible citizenship; (iv) an instrument for promoting environmentally sound sustainable development; and (v) a method of facilitating poverty alleviation. Looking at the above, it is very obvious that the aim of promoting environmentally sound sustainable development and a method of facilitating poverty alleviation is focus on sustainable learning approach.

With young people among the big losers of the recent financial crisis, vocational education and training (VET) are often seen as the silver bullet to the problem of youth joblessness [5]. The above excerpt goes to mean that the problem of youths joblessness can be solve through a sustainable curriculum which prepares the youths with sustainable experiences and skills to survive in the post oil economy in Nigeria. A sustainable business education curriculum ought to be characterized with duality of general and vocation experience. While the former aims to provide graduates with general education or academically based knowledge, VET have a duty to provide students with practical based knowledge and skills necessary for specific occupation and self-sustenance.

Developing a sustainable business education curriculum had better focus on successfully developing an inter-linkage strands that will involve entrepreneurial skills development, work-based skills development, a changed in perceptions of skills and building employers' assignations. Entrepreneurial skills development spirit enhances the self-sustainable skills of students. Work-based skills drives help graduate understand the operating aptitudes of work-based environment. Changing perception skills willpower expose students to value of self-sufficient skills and remove the stigma attached to craftsmanship education as education for the never-do wells. While employers' collaboration motivation exposure grants graduates opportunities for real time experiences and participations.

Every single core subject have their core curriculum contents. However, it is observed that there is the lack of business development skills in most of the course contents. Thus, the need for sustainable business education 
curriculum should not be viewed as a concern for business education graduates, but rather an issue that need to be holistically appropriate to all core subject areas in all professions. This is because, the high rate of unemployment, and the call for skill development geared towards building "non-oil-reliant" economy affects the general education system. Consequently, this paper is looking at education for business and not necessarily business education. On the other land, the concern of sustainable curriculum is moving from theoretical skills based curriculum, to a practical business focus curriculum that is capable of exposing graduates to the business concern of their chosen careers rather than depending solely on gaining employment for sustainability. It is pertinent to note that every single career course has an economic focus. That is, it is concerned with sustenance after graduation, thus, it is not out of place to understand the business direction of the course, which can only be made possible through building the business focus of the course in terms of curriculum integration.

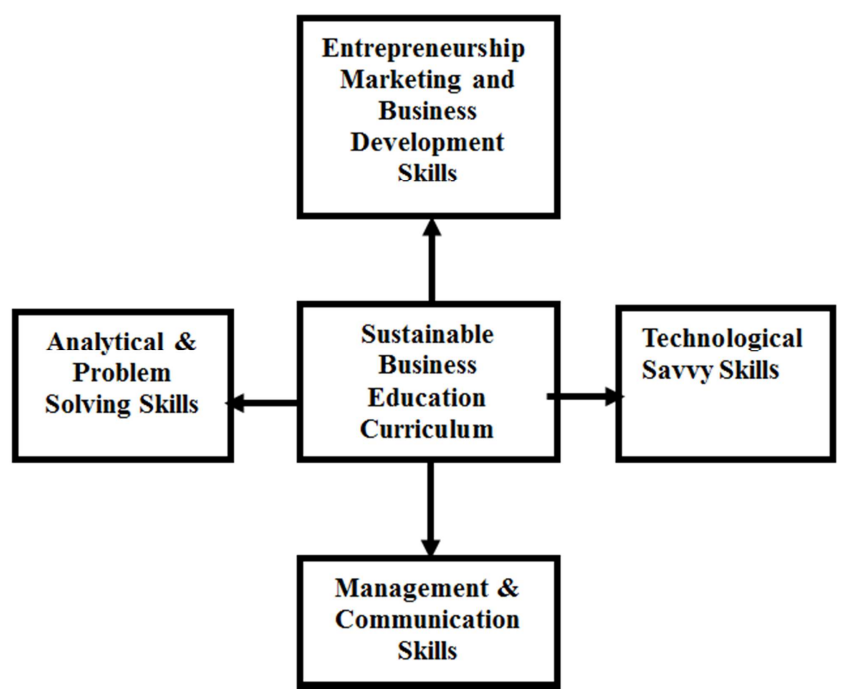

Figure 2. Business Education Curriculum for Sustainability - A Praxis for all professions

Business education for sustainability should build practical skills that are capable of exposing and expanding the core professional knowledge of all students with the notion to prepare them for gainful and self-sustaining engagements. In other words, students are not expected to pigeonhole their knowledge in the $21^{\text {st }}$ century in a single focused career. Students from all professions should be exposed to all skills as depicted in figure 2 above to prepare them for the business world and the society at large.

\section{Conclusion}

The recent economic recession and the high rate of unemployment has drawn attention of both the government and other institutions on the need for developing various sectors of the economy and redirect focus from oil boom economy. The over reliance on oil and gas revenue for national development has created "economic laziness" among many Nigerian graduates which has retard the progress of the nation. The encouragement for post oil boom economy calls for developing the infrastructural base and non-oil sectors of the nation, which has the capacity to attract both domestic and global investment, now and in the future. It also calls for development of skills and competencies that will service the emerging sectors. More importantly, in the post oil boom economy the micro-economic industries should be characterized with self-sufficient small and medium enterprises, because the teeming population of the nation needs skills and exposures that will prepare them for self-sustainability rather than trusting too profoundly on gainful employment.

It is germane therefore, that educational institutions curriculum be developed towards building a nation whose focus is on encouraging the teeming youths to take up participation in self-reliant occupation rather than waiting for employment from established institutions. This is where the need for sustainable business education curriculum is imperative, as it has the capacity to bridge the gap that exist between general education base curriculum and practical business focus curriculum. A nation like Nigeria, at its present economic situation and for future sustainability of both the nation and its citizens requires a system of education that can produce graduates with dual skills experiences to enable them become productive citizens of the society. One major cause of high rate of unemployment of graduates in Nigeria, is the lack of business competencies, which is what sustainable business education curriculum came to correct. Sustainable business curriculum otherwise called green skills curriculum enable students to develop skills and competencies for both cognitive and psycho-productive focus. It is a curriculum that shows the business aspect of every career or occupation. It teaches self-sustainable development endeavors. Job creation is key to tackling high and increasingly persistent unemployment and underemployment in many countries [20]. This is why it is necessary to design a green curriculum whose objective is to develop citizens with both "white and blue collar" experiences. For the business education programme to become relevant and functional it must not only seeks to achieve the goals and objectives of the general business and basic business education but also seek to give learning in the $21^{\text {st }}$ century skills basic for employability in the global labour market [2]. The post oil boom economy in Nigeria will not depend too much on gainful employment, but more on self-built ventures, which is the greatest drivers of modern economies. As experiences has shown from the western economies. It is on this premise that the paper focused on bridging the sustainable skills gap on business education curriculum for post oil boom economy in Nigeria. There is a lacuna on the practical contributions of the business education curriculum to building a sustainable career path by graduates of different professions in Nigeria. The gap has automatically been filled by the depth of this paper. 


\section{Recommendations}

The following recommendations are made:

1. Re-assessment and re-evaluation of the business education curriculum by educational institutions should be carried out to determine its practical functionality in the Nigeria economy.

2. Efforts should be made to develop and design a curriculum whose focus is sustainable $21^{\text {st }}$ century skills relevant for both gainful and self-sufficient employment.

3. The business education new curriculum for sustainability should be unified for all business education programmes in Nigeria.

4. The curriculum should have a technological focus that is capable of bridging labour market gap within Nigeria and the global system.

5. The curriculum should be designed to make provision for apprenticeship and practical exposure on selfsustainable skills.

6. There should be collaborations and linkages between educational institutions and practical private oriented firms for training of students on sustainable selfsufficient skills that will help establish graduates after their education.

7. The curriculum should also emphasis on the culture of self-sufficiency and the needs for private owned oriented firms in the $21^{\text {st }}$ century economy.

8. To adequately implement a sustainable business education curriculum, there should be functional practical laboratories, workshops and studios that are equipped with modern technological apparatuses for practical exposure of students.

9. The curriculum should be practicable, functional and adaptable in the Nigeria education system.

10. The new curriculum should accommodate the need for its application in other non-business related core courses to enhance the business orientation of the students in those careers.

\section{References}

[1] Afolabi, A. (2015). The effect of entrepreneurship on economy growth and development in Nigeria. International Journal of Development and Economic Sustainability, 3 (2), 49-65.

[2] Aquah, P. A. (2014). Enriching the business education curriculum for relevance in the global workforce. Global Journal of Human Social Science: A Linguistics and Education, 14 (7), 1-6.

[3] Brennan, R., and Skaates, M. A. (2005). An international review of the business-tobusiness marketing curriculum. Marketing Education Review, 15 (3), 77-89.

[4] Commonwealth of Australia (2010). Sustainability curriculum framework: A guide for curriculum developers and policy makers: Retrieved www.envirnment.gov.an/sustainability/educ.24-05-2017.
[5] Eichhorst, W, Rodinguez-Planas, N. Shlmidle, R. I. and Zimmerman, K. F. (2012). A roadmap to vocational education and training systems around the world IZA. Discussion Paper Series, 7110, 1-46.

[6] Elder, J. L. (2009). Higher education and the clean energy, green economy. Education Review, 44 (6), 108-109.

[7] Ezeonwuka, I. F. O (2014). Transforming Nigeria's economy on the path of sustainable development in the $21^{\text {st }}$ century. Challenges and reflection. Journal of African Studies, 3, 67-79.

[8] Kee Luen, W (2008). Curriculum Gaps In Business Education A Case Study Of Stakeholders' Perceptions. Thesis submitted for the degree of Doctor of Education at the University of Leicester, October, 2008.

[9] Louw, W. P. (2013). Green curriculum: Sustainable learning of a higher education institution. The International Review of Research in Open and Distributed Learning, 14 (1), Retrieved at: www.irrodl.org.24-05-2017.

[10] Lucas, U., and Milford, P. (2003). Key aspects of teaching and learning in accounting, business, and management. In A Handbook for Teaching and Learning in Higher Education: Enhancing Academic Practice, 2nd Edition, eds. H. Fry, S. Ketteridge, and S. Marshall, 391-412. Oxon: Routledge.

[11] Lungu, C. I, Caraiam, C. and Dascalu, C. (2013). Education for sustainability: A prerequisite for post crisis economic competitiveness with possible inference for Romania. Theoretical and Applied Economics, 20 (5), 53-70.

[12] Odunaike, K. O. and Amoda, B. (2008). The impact of vocational education on business education students at Tai Solar University of education, Ijebu-Ode Ogun State. Journal of Business Education and Entrepreneurial Development (JOBEED), 1 (1), 81-95.

[13] Ohiwerei, F. O. and Azih, N. (2010). Comparative programmes of business education in Nigerian Universities. A Case Study of Ambrose Ali University, Ekpoma and Delta State University, Abraka. Current Research Journal of Social Sciences, 2 (2), 58-64.

[14] Pavlova, M. (2012). Generic green skills. Can they be addressed through technology education? In proceedings of $7^{\text {th }}$ Biennial International Conference on Technology Education Research: Best Practice in Technology, Design and Engineering Education. Griffith Research Online. Retrieved http://www.griffith.edu.au/comference/technicaleducation- research.conference-2012.24-05-2017.

[15] Oviawe, J. I., Uwameiy, R. and Uddin, P. S. O. (2017) Bridging skill gap to meet technical vocational education and training school-workplace collaboration in the $21^{\text {st }}$ century. International Journal of Vocational Education and Training Research, 3 (1), 7-14. Available at: http://www.sciencepublishggroup.com(j)(i)vetr.27- 052017.

[16] UNESCO (2006). United Nations decades of education for sustainable development: Retrieved at: http://portal.unesco.or/education 24-05-2017.

[17] United Global Compact (2011). The University of SouthAfrica communication on progress. Pretoria: Unisa Press. 
[18] UNESCO (2009). Educational sector: United Nations decades on education for sustainable development (2005-2014): International Implementation Scheme. Retrieved at: http://unesdoc.unesco.org(images/0014/001486/148654.pdf 24-05-2017.

[19] Usoro, E. B. (2016). Business education: Skills acquisition and development for posterity. Uyo: Heritage Digi-Link Int'1 Ltd, 1-58.

[20] World Economic Forum (2014). Matching skills and labour market needs: Building social partnerships for better skills and better jobs: Global Agenda Council on Employment, 1-28. 